\title{
PRINCIPLES AND APPLICATIONS OF POLYMERASE CHAIN REACTION IN MEDICAL DIAGNOSTIC FIELDS: A REVIEW
}

\author{
Marcela Agne Alves Valones ${ }^{1 *}$; Rafael Lima Guimarães ${ }^{1}$; Lucas André Cavalcanti Brandão ${ }^{1}$; \\ Paulo Roberto Eleutério de Souza $^{2}$; Alessandra de Albuquerque Tavares Carvalho ${ }^{1}$; Sergio Crovela ${ }^{1}$
}

${ }^{1}$ Universidade Federal de Pernambuco, Recife, PE, Brasil; ${ }^{2}$ Universidade Federal Rural de Pernambuco, Recife, PE, Brasil

Submitted: May 05, 2008; Approved: February 25, 2009.

\begin{abstract}
Recent developments in molecular methods have revolutionized the detection and characterization of microorganisms in a broad range of medical diagnostic fields, including virology, mycology, parasitology, microbiology and dentistry. Among these methods, Polymerase Chain Reaction (PCR) has generated great benefits and allowed scientific advancements. PCR is an excellent technique for the rapid detection of pathogens, including those difficult to culture. Along with conventional PCR techniques, Real-Time PCR has emerged as a technological innovation and is playing an ever-increasing role in clinical diagnostics and research laboratories. Due to its capacity to generate both qualitative and quantitative results, Real-Time PCR is considered a fast and accurate platform. The aim of the present literature review is to explore the clinical usefulness and potential of both conventional PCR and Real-Time PCR assays in diverse medical fields, addressing its main uses and advances.
\end{abstract}

Keywords: Conventional PCR; Real-Time PCR; Molecular Biology; Methods of molecular detection

\section{INTRODUCTION}

The development of molecular biology was one of the greatest achievements in biological science in the century XX. The discovery of Polymerase Chain Reaction (PCR) brought enormous benefits and scientific developments such as genome sequencing, gene expressions in recombinant systems, the study of molecular genetic analyses, including the rapid determination of both paternity and the diagnosis of infectious disease $(73,99)$. PCR enables the in vitro synthesis of nucleic acids through which a DNA segment can be specifically replicated in a semi-conservative way. It generally exhibits excellent detection limits $(19,101)$.

Recently, a technological innovation of PCR, known as RealTime PCR, has become increasingly important in clinical diagnostics and research laboratories due to its capacity for generating quantitative results. This technique allows accompanying the reaction and presentation of results in a faster and more accurate fashion than conventional PCR, which only displays the qualitative results $(50,62,73)$.

The aim of the present study is to outline the principles and applications of conventional PCR and Real-Time PCR techniques in some medical sciences. It also seeks to evaluate and discuss the indications, uses and advantages of these techniques, as well as their advances in various medical areas.

\section{PCR TECHNOLOGY CONVENCIONAL PCR}

PCR was developed in the 1980s by Kary Mullis, who received the Nobel Prize in 1994 (14). Since its description, this technology has caused a veritable revolution in biological research, establishing the agreement of basic biological processes in applied areas involving diagnoses and genetic improvements for plants and animal (101). PCR enables the synthesis of specific DNA fragments using a DNA-polymerase enzyme, which takes part in the replication of the cellular genetic material. This enzyme

*Corresponding Author. Mailing address: Rua Quarenta e oito, 395, apto. 201, Espinheiro, Recife, Pernambuco, Brasil. CEP 52020-060. Tel.: 0 xx 81 342-60449, 81 3222-2883, 81 9252-8488. E-mail: mavalona@hotlink.com.br 
synthesizes a complementary sequence of DNA, as a small fragment (primer) is connected to one of the DNA strands in the specific site chosen to start the synthesis. Primers limit the sequence to be replicated and the result is the amplification of a particular DNA sequence with billions of copies $(66,73)$.

The development of tools for amplifying DNA segments has generated enormous benefits in gene analysis as well as the diagnosis of many genetic diseases and the detection of bacterial, viral and fungal pathogens $(4,72,73,99)$. Another useful PCR application is the cloning of a particular DNA fragment, which allows the study of gene expression and has considerable potential in forensic medicine (94).

\section{REAL-TIME PCR}

The possibility of Real-Time PCR monitoring has revolutionized the quantification process of DNA and RNA fragments. Real-Time PCR allows the precise quantification of these nucleic acids with greater reproducibility. This technique provides a sensitive method for the accurate quantification of individual species, which could be very relevant to the diagnosis of pathogens and genetic diseases. Advantages of Real-Time PCR include the ease of quantification, greater sensitivity, reproducibility and precision, rapid analysis, better control of quality in the process and a lower risk of contamination $(62,73)$.

Real-Time PCR requires a thermocycler with an optical system to capture fluorescence and a computer with software capable of capturing the data and performing the final analysis of the reaction. The programs available from diverse manufactures exhibit differences regarding sample capacity, method of excitation and total sensitivity. There are also differences between regarding the data processing. The emission of fluorescence generates a signal that increases in direct proportion with the amount of PCR products. Fluorescence values are recorded during each cycle and represent the amount of amplified product. The fluorescent composites used are $S Y B R^{\circledR}$ Green and $\operatorname{TaqMan}^{\circledR}(50,73)$.

\section{Real-Time PCR Technology \\ Forms of detection}

The fluorescence signals are proportional to the amount of PCR product generated by the fluorescent dyes, which are specific to double-stranded DNA (dsDNA), or by sequencespecific oligonucleotide probes.

\section{SYBER Green I dye}

SYBR Green I is the most used dsDNA binding-specific dye in real-time PCR. Its fluorescence is undetectable when not bound to dsDNA. Its binding affinity to DNA is 100 times greater than that of ethidium bromide, which is the most often used dsDNA binder in conventional PCR $(64,113)$. The disadvantage to SYBR Green $I$ is that it binds to any dsDNA, such as non-specific amplification products and primer dimers. Amplified non-specific products affect the efficiency of the amplification of specific products. Thus, analysis should be optimized in such a way that non-specific amplification does not occur. Melting curve analysis after the PCR reaction is a good practice for controlling the formation of dimer primers. Fluorescence is measured as a function of temperature, gradually diminishing with the increase in temperature of the amplified product (74). However, upon reaching the temperature at which the double-stranded DNA separates, the stain detaches and fluorescence drops off abruptly (84). Once optimized, detection by SYBR Green I is highly sensitive to the identification of a single molecular target in the reaction mixture. The greatest advantage is that it can be used with various pairs of different primers, making it less expensive than a probe.

\section{Minor groove DNA binder probes (MGB)}

MGB probes consist of oligonucleotides from 14 to $15 \mathrm{pb}$ in length that carry a fluorescent dye in terminal $5^{\prime}$ as well as a nonfluorescent quencher and MBG in terminal 3', which specifically hybridizes with a target sequence. MGB is released from a probe that binds to the minor groove of the dsDNA (consisting of part of the MGB probe and complementary target sequence by which it is hybridized) related to the nucleotide sequence. The MGB increases binding stability to the amplification probe (51).

\section{Hybridization probes}

Oligonucleotide probes marked with fluorophores are used for the detection of specific sequences $(16,115)$. The amount of the fluorescence may be related to the amount of PCR product through the product-dependent reduction of a quencher fluorophore and a reporter or through an increase in the fluorescent resonance energy transfer (FRET) from a donor fluorophore to a receptor. The donor probes are marked in the 3 ' terminal portion with a reporter fluorophore (often 6carboxifluorescein, FAM) and the acceptor probes are marked in the 5 terminal portion with an acceptor fluorophore (cyan dyes Cy3, Cy5; 6-carboxy-4,7,2',7'-tetrachlorofluorescein, TET; 6-carboxy-N, N, N', N"'-Tetramethylrhodamine, TAMRA; 6carboxirhodamine $\mathrm{X}, \mathrm{ROX})$. Only the donor fluorophore is excited in such a way that no fluorescent acceptor is detected in the free-floating probes. During the annealing phase of the primer, the probes hybridize adjacently to the single-stranded DNA (ssDNA) and the excitation energy is transferred from the donor to the acceptor. Four oligonucleotides are used in this format: two primers and two probes. The amount of fluorescence is proportional to the amount of target DNA generated during the PCR process (10).

\section{TaqMan Probes}

The first fluorescent probe developed for real-time PCR was 5 'nuclease, which is commonly referred to by the name TaqMan. 
A TaqMan probe is a short oligonucleotide (DNA) that contains a 5 'terminal reporter fluorophore similar to fluorescein and a 3 'terminal quencher. Intact probes do not emit fluorescence because they are bound (quenched). Two events must occur to generate a fluorescent signal. First, the probe must bind to a complementary DNA strand at $60^{\circ} \mathrm{C}$. Second, at this temperature, Taq polymerase, the same enzyme used for the PCR, must cleave the 5 'terminal TaqMan probe (5'nuclease activity), separating the fluorescent dye from a quenching dye. The quencher is released from the fluorophore, which now fluoresces after excitation $(28,33)$.

\section{Molecular beacons}

Tyagi, Kramer (106) first evaluated molecular beacons combine an oligonucleotide capable of forming a stem-loop structure with the quencher-reporter pair. Specifically, an oligonucleotide probe with a binding domain to the antisense target flanked by two short arms of complementary sequences is marked in one terminal with the reporter dye and in the opposite terminal with the quencher dye. In the absence of the target, the short arms anneal to form a hairpin structure (stemloop), forcing the flourophore toward the quencher. In this conformation, the molecular beacon is 'dark'. Through hybridization with the target sequence, the hairpin structure opens, separating the fluorophore and quencher and resulting in the restoration of fluorescence ('shining' state) (107). The transition between the dark and shining state of the molecular beacon allows the differentiation between bound and unbound probes $(49,106,108)$.

\section{Sunrise primers}

Sunrise $^{\mathrm{TM}}$ Probes (Oncor, Inc.) (70) function in a similar manner to TaqMan probes. They are also doubly marked with a flourochrome in the 5 'terminal portion. The 3 ' region of the probe is the specific target and the $5^{\prime}$ region is the complementary target, such that when not extended (not incorporated in the amplicon), it forms a hairpin structure that holds the quencher and reporter marker together. When the probe is extended and integrated within a dsDNA molecule, the quencher and reporter are kept apart by a recently copied complementary strand. Like conventional TaqMan, Sunrsire primers require a new probe for each amplification (109).

In the first phase, the Sunrise primer is extended with the forward primer. This extended product serves as the template for the reverse primer in the second phase. In the end, polymerase opens the hairpin structure and a double-stranded PCR product is formed, in which the reporter and quencher are separated (70).

\section{Scorpion primers}

Scorpion primers are structurally and functionally related to molecular beacons, but serve as primers in PCR. Two different formats are possible: 'stem-loop' and 'duplex'. In both cases, the marking mechanism is intra-molecular. The basic elements of scorpions are: (i) a PCR primer; (ii) a PCR stopper to prevent the cross-reaction of a probe; (iii) a sequence-specific probe; and (iv) a fluorescence detection system containing a minimum of one flourochrome and one quencher. After PCR amplification of the scorpion primer, the resulting amplicon contains a sequence that is complementary to the probe, which is restituted a single strand during the denaturation stage of each PCR cycle. With cooling, the probe is free to bind to this complementary sequence, producing increased fluorescence. Thus, the quencher is not increased in the proximity of the fluorophore (110).

\section{PRINCIPLES AND APPLICATIONS IN VIROLOGY}

Recent advances in molecular biology have made possible the detection and characterization of viral nucleic acids. Methods such as PCR enable the amplification of specific regions of interest. Technological improvements in the detection systems of gene sequences provide a complete viral characterization, determining the subtype, genotype, variation, mutation and standards of genotypic resistance of these viruses $(56,71)$. The recent development of Real-Time PCR has facilitated the detection and amplification of PCR products. This method is useful in quantifying a larger range of sequences of viral nucleic acids than most quantitative methods. Moreover, the qualitative detection also is possible. Quantification and qualification are carried out automatically. Examples of the detection and quantification of specific viral regions have been published and this field of study is growing very quickly $(39,72)$.

The implementation of molecular methods has resulted in progress regarding the diagnosis of many viruses and the monitoring of antiviral therapy, especially HIV-1 (Human Immunodeficiency Virus type 1) (92), HBV (Hepatitis B Virus) (79) and HCV (Human Cytomegalovirus) (23). It has also led to the development of amplification assays on nearly all human viruses, including those that are more easily be cultivated, such as HSV-1 and HSV-2 (Herpes Simple Virus type 1 and 2) (25).

The newer molecular methods are advantageous, mainly in cases for which the viral culture routine is not available. The introduction of molecular biology in clinical diagnosis is important to reducing the use of viral culture techniques. The implementation of automatic extraction and detection, combined with an extensive quality control program, should convince the clinical community that molecular diagnosis is important in clinical virology $(46,120)$. The ability to exclude viral infections can help avoid unnecessary therapies, such as powerful antibiotics and antiviral medicines, as well as reduce costs incurred on the part of patients. Thus, these techniques are important to establishing the best therapeutic protocol $(56,72)$. 
Real-Time PCR is extremely useful in the study of viruses that cause infectious diseases. The majority of published assays show an increase in the frequency of viral detection. This is therefore an attractive technology for many virological fields (56). It is valued for its quickness in the detection of viral variants and the syndromes caused by these viruses (27). The method contributes to epidemiological studies due to its capacity to quantify nucleic acids in a single reaction $(46,120)$. New chemicals have allowed a better discrimination of multiple viral genotypes within a single reaction (44) and have provided an alternative viral detection method based on morbidity and mortality assays.

For many years, the diagnosis of viral infections has been hampered by the high costs, laboratory time and qualified personnel required in the cell culture process. An additional negative factor is the low sensitivity and slow development of many viruses in artificial mediums. PCR technology facilitates and improves detection, thereby facilitating the diagnosis of a certain number of these viruses (100).

\section{PRINCIPLES AND APPLICATIONS IN MYCOLOGY AND PARASITOLOGY}

The ability to accurately identify microorganisms is fundamental to all aspects of fungal epidemiology and diagnosis. In phytopathology, the early identification of diseasecausing agents is essential to the recognition of pathogens (60). In the last ten years, advancements have been made in the molecular diagnosis of fungi through PCR technology. Unlike conventional methods, samples can be tested directly through PCR and isolated without the need for cultures. The technique is fast and highly specific. It can be used to detect trace amounts of fungal DNA from environment samples before symptoms occur. It therefore allows the implementation of early disease control methods. PCR can be performed routinely and does not require specialized skill to interpret the results. The technology can also offer more accurate quantitative data, providing additional information necessary for decision making and the assessment of how effective fungal agents are in biological control. Since its introduction in the mid 1980s, PCR has become the cornerstone of DNA technology and has cleared the path for the creation of innumerous associated technologies. It is remarkable for its ability to detect amounts of DNA amplified from one or few original sequences. Conventional PCR is not quantitative, but rather qualitative. It has been used to detect, monitor and identify fungi from an entire set of environmental samples and is the core of molecular fungal diagnostics (4).

Fluorescent PCR in situ utilizes fluorescently marked primers or probes to detect and locate fungi in fixed environmental samples following semi-permeabilization (102). The fluorescence of the primers or probes is detected using a confocal microscope. This technique allows the direct detection of the organism in the sample. It also shows the spatial distribution, interactions with the host and other organisms. Bago, Piche, Simon (5) used in situ PCR to detect and locate infections caused by Arbuscular Mycorrhiza fungi. The scope of PCR is infinite (5). It can be used to investigate either a single species or entire communities $(22,35,80)$.

Pneumocystis jiroveci (a fungus previously denominated Pneumocystis carinii) can cause severe pneumonia in patients infected with HIV or otherwise immunosuppressed, but its detection is restricted to the microscopy of specimens in the respiratory tract. Microscopy for the detection of $P$. jiroveci generally involves the use of stains. Immunofluorescence is more sensitive than these stains, but is more expensive and requires specialized facilities. PCR is more sensitive, especially in patients not infected with HIV, and can therefore be of considerable usefulness (36). PCR specificity is limited, but as this microorganism is an omnipresent commensal, it can be detected through PCR in the absence of the disease (37).

Another example of the use of PCR technology in mycology is in the detection of infection from Aspergillus ssp. in patients with neutropenia. This disease is notoriously difficult to diagnose due to the poor sensitivity of the culture method and the difficulty of finding histopathological specimens in individuals with low platelet counts. Early treatment is essential to achieving the best results. PCR can reduce the time required for the specific diagnosis (111). Real-Time PCR has been successfully used to quantify the number of pathogens $(7,13,21$, 112 ), thereby assisting in decisions regarding how to treat fungal diseases and assess the effects of fungi (57).

Parasitological diagnostics can be assisted by molecular methods. Many parasites are not cultivable in laboratory and diagnosis principally relies on serology and relatively less sensitive microscopy. Microscopy remains a support to the diagnosis of malaria, but due to its greater sensitivity, PCR can diagnose this illness in even in difficult situations. Plasmodium species can also be detected in different infections, which can hinder microscopic discernment (99)

\section{PRINCIPLES AND APPLICATIONS IN MICROBIOLOGY}

Conventional PCR has been used for over a decade in clinical microbiology laboratory research for the identification of microbial pathogens (114). However, for a number of reasons, this technique has been restricted to the detection of microorganisms that either have slow growth or cannot be cultivated. Most tests based on conventional PCR involve multiple steps and, therefore, require careful expertise. These assays often require both time and culture-based methods, thereby increasing the costs. Conventional PCR also involves an open-reaction system, which is more susceptible to contamination from foreign amplified DNA. Conventional PCR 
assays have been developed for Bacillus anthracis, the Anthrax agent (9) and Variola Major (26), but clinical validation of these assays is limited due to the unavailability of the human specimen. Real-time PCR has important, immediate implications to diagnostic tests in the clinical microbiology laboratory. The enhanced sensitivity, ease of use and quickness of this technology make it an attractive alternative for detecting microorganisms in humans (18).

\section{Bacteriology}

Anaerobic bacteria are involved in a broad range of infections that are commonly associated to considerable morbidity and mortality rates $(98,116)$. Although different types of these bacteria are frequently found in diverse infections, evidence suggests that a number of these clinically important pathogens are as yet poorly characterized due to the inadequacy of conventional anaerobic bacteriological methods and phenotype tests. According to recent studies, 50 to 75 percent of anaerobic bacteria are satisfactorily characterized and 27 percent of laboratories indicated that they have never identified such bacteria (2). This occurs mainly because conventional identification is complicated, expensive and time-consuming. It is also not reliable, as it is based on antiquated taxonomy (97).

Molecular detection methods are a powerful means of identifying these pathogens in the study of the parasite-host relationship, clarifying the taxonomic positions of known pathogens. Thus, there is a growing trust in genotyping for microbial characterization. Genotypes are more specific and more easily quantified and standardized between different organisms than traditional phenotype markers. In the last ten years, a number of advances have been made in molecular bacterial diagnostics, including the greatest discovery: PCR technology $(97,116)$. Real-time PCR has recently emerged and has been used in the detection and quantification of anaerobic bacteria. This provides users with the ability to amplify DNA as well as detect and confirm the specific sequences of microorganisms. Each cycle in real time also provides greater sensitivity.

PCR for the detection of Lactobacillus, Gadnerella vaginallis and Mycoplasmas hominis, genital tract bacteria was used (119). In another study, Aliyu et al. (1) reported the importance of Fusobacterium necrophorum as a cause of acute pharyngitis. There are a considerable number of studies using real-time PCR in the characterization of bacterial communities in the human intestine $(6,40,58)$.

The diagnosis of infections due to specific bacteria has greatly benefited from molecular detection. Many of these bacteria are public health concerns, such as Micobacterium tuberculosis, Chlamydia Trachomatis, Neisseria gonorrheae and Bordetella pertussis. Tests based on molecular methods have the advantage of avoiding days or weeks of delay and allow early recognition and treatment. Commercial assays are available for M. tuberculosis, Micobacterium avium complex, C. trachomatis and N. gonorrheae (116).

Due to the increased sensitivity, the use of molecular detection methods for sexually transmitted bacteria has led to an increase in the proportion of cases confirmed in laboratory of the diseases such bacteria cause. Traditional sexual health exams require the use of a speculum in women and a urethral swab in men. These exams require special equipment and can cause both embarrassment and discomfort. Molecular detection is a noninvasive method, which increases trust and reduces discomfort. Molecular testing also encompasses a range of genital pathogens, such as C.Trachomatis, $N$. gonorrheae, etc. (100).

\section{PRINCIPLES AND APPLICATIONS IN DENTISTRY}

The recognition of the universality of the genetic code in living organisms has been essential to the development and application of genetic technologies. A number of methods have been employed in dentistry to better understand and diagnose infectious agents that lead to maxillofacial infections, thereby obtaining an evaluation of risk patients might have to caries, periodontal disease and other oral conditions (47). These methods include cultures, microscopy, immunofluorescence assays and DNA probes. More recently, polymerase chain reaction has been introduced. Many different types of clinical samples have been used for PCR analyses, including blood, sweat, semen, strands of hair and saliva. Saliva is a potential source of genetic material for diagnostic tests in oral and systemic diseases. With the recent interest in associations between systemic disease and the mouth as well as the successful use of saliva in molecular diagnostics, saliva sampling may soon become part of the routine dental exam. Furthermore, as a medium where biologically active proteins and exogenous substances are found, saliva is also a source of patient DNA $(82,88,103)$ as well as cariogenic and periodontopathgenic microorganisms $(32,42,48,76)$.

The publication of the PCR technique was a revolutionary watershed for medicine and science. It has recently become a standard diagnostic and research tool in dentistry. The literature reports the uses of PCR for the study of factors involved in periodontal disease, dental caries, endodontic infections and oral cancer $(90)$.

\section{Periodontal disease}

Diverse methods have been reported for the rapid detection of periodontal pathogens, such as immunological and immunoenzymatic assays, protein electrophoresis and DNADNA hybridization. However, these methods exhibit different limitations that can lead to false positive results as well as crossreactions $(3,17)$.

PCR is an excellent tool for directly identifying periodontal pathogens in subgingival samples. Due to its sensitivity and 
specificity, it is also a rapid, efficient method for detecting, identifying and differentiating organisms, but appropriate standardization is necessary (24). Diverse molecular means are often used to identify periodontal pathogens, but PCR is considered the easiest and fastest method in clinical samples (83). PCR may soon become the ideal detection method for periodontal pathogens due to its greater ease of use in comparison to cultures associated with biochemical identification tests. It also demonstrates excellent detection limits with few cross-reactions under ideal conditions (19).

In researching the possible involvement of human viruses in periodontal disease, Parra, Slots (77) determined the prevalence of Human Cytomegalovirus (HCMV), Epstein-Barr Virus Type I and II (EBV 1 and 2), Herpes Simples Virus (HSV), Human Papillomavirus (HPV) and Human Immunodeficiency Virus (HIV) in the crevicular fluid of individuals with various forms of periodontal disease. Viral identification was carried out using the PCR technique. The study provided evidence of human viruses in the crevicular fluid of the most advanced adult periodontal lesions. Ssygun et al. (91) confirmed the frequent presence of HCMV in crevicular samples of chronic periodontal lesions and suggested a strong relation between HCMV and EBV-1 in subgingival areas with deep furrows accompanied by a loss of insertion.

In studying the expression of virulent factors of Porphyromonas gingivalis in periodontitis, Shelburne et al. (93) modified methods of quantitative measurements and gene activation, and discovered (real-time) quantitative reverse transcription of PCR (QRT-PCR) to examine gene expression in vivo in the oral cavity of the anaerobe $P$. gingivalis. The authors described these initial results with QRT-PCR using a selection of virulent factors. The effectiveness of the PCR method in the detection of $P$. gingivalis from saliva samples was compared to bacterial cultures performed by Matto et al. (59), demonstrating that PCR detected the bacteria in saliva three time more frequently than the culture method.

The PCR was also used by Sakamoto et al. (89) for the detection and identification of Treponema socranskii associated to periodontal disease. This pathogen is related to an inflammation in the gingiva in both children and adults. $T$. socranskii was detected more frequently in subgingival plaque samples than in saliva samples.

Studies have detected Actinobacillus actinomycetemcomitans using PCR in the most distinct patterns in a population with (70\%) and without (19\%) periodontal disease. These studies have also shown the sensitivity and specificity of PCR in comparison to traditional culture methods $(65,104)$. Okada et al. (75) used PCR to detect the presence of A. actinomycetemcomitans and $P$. gingivalis in dental plaque samples from children using their toothbrushes. The research indicated that such bacteria are rarely present in the oral cavity of healthy children. In 2001, the researchers also detected the presence of $P$.
Intermédia, nigrescens, B. forythus, T.denticola and C. rectus in periodontal disease.

Real-Time PCR offers a sensitive, efficient, faithful approximation for quantification. Using the TaqMan ${ }^{\circledR}$ systems, Lyons et al. (54) were able to determine both the amount of $P$. gingivalis and total number of bacteria present in bacterial plaque without the use of cultures. Furthermore, this allowed the authors to determine the percentage of $P$. gingivalis in a complex sample.

Sakamoto et al. (88) compared conventional PCR, real-time and the culture method in the detection and quantification of periodontopathogenic bacteria, including A. actinomycetemcomitans, B. forsythus, $P$. gingivalis, T. denticola and $T$. socranskii in both saliva and subgingival plaque. There was satisfactory agreement between the results from conventional and real-time PCR for all the saliva samples. The use of real-time PCR optimally simplified the process and was able to determine the amount of periodontopathogenic bacteria within one hour. These bacteria were more frequently detected in the saliva than the subgingival plaque. The study suggests the saliva is as good, or better, than subgingival plaque for the detection and quantification of periodontal bacteria in the oral cavity.

Therefore, PCR has revolutionized understanding regarding periodontal pathogens. These studies not only permit the diagnosis of known pathogens, but also contribute toward the identification of new pathogens involved in periodontal disease (47). PCR is expected to be successful in the microbiological diagnoses and periodontal disease $(89,90)$.

\section{Dental Caries}

The group mutans, which encompasses cariogenic bacteria, has seven species: Streptococcus cricettus, S. ratti, S. mutans, S. sobrinus, S. downei, S. ferus and S. macacae $(69,108)$, of which S.mutans and $S$. sobrinus are more frequently isolated from the human oral cavity $(38,108,117)$. For epidemiological studies on caries, a rapid, sensitive, simple method is needed for the identification and differentiation of these microorganisms. A number of methods have been used to identify these isolated species in the oral cavity, such as biochemical, immunological and genetic methods (41). Different techniques are used in conjunction in order to achieve reliability in species identification. This requires time and considerable ability, and the results are often unsatisfactory. Species characterization based on DNA testing is currently widely accepted, as phenotyping is a reflection of gene expression (105). As mentioned above, PCR was recently introduced to solve these problems. Tests related to genotyping are currently being used due to the possibility of its being more sensitive and specific (118).

PCR appears to be convenient for studying the epidemiology of disease in isolated individuals. It may prove useful in the identification of species associated with dental caries and their 
location in the ecological niches, thereby helping to clarify the progression of the carious process (82). PCR has the potential to replace conventional identification methods, such as biochemical and immunological tests (43) The discriminative power of PCR in the differentiation of $S$. mutans and $S$. sobrinus serotypes and lineages was investigated by Saarela et al. (87), who found that PCR exhibited good results in differentiating $S$. mutans lineages and the technique is appropriate for epidemiological studies on this bacterium.

Rupf et al. (86) presented a competitive PCR method for the specific quantitative determination of $S$. mutans. This method allowed a quick, exact determination of unknown quantities of this bacterium and provided an efficient means for evaluating the risk of caries in patients as well as monitoring the efficiency of preventative and therapeutic measures.

\section{Endodontic Infections}

With the development of molecular methods based on the detection of specific genomic regions, it became possible to identify microbial species in infected root canals that had never been seen by means of the conventional culture procedure. Examples of bacterial species that were only detected in canals through molecular methods and that are currently considered important endodontic pathogens include Treponema denticola, Dialister pneumosintes, Filifactor alocis, Tannerella forsythia, Treponema malthophilum, Treponema socranskii and Prevotella tannerae (96). Based on current studies, molecular methods can be used to characterize the micro-flora associated to endodontic infections (47). Using PCR, Bogen, Slots (12) sought to determine the prevalence of $P$. endodontalis, $P$. gingivalis, $P$. intermédia and $P$. nigrescens in 20 with refractory periapical lesions. The authors concluded that bacteria that produce black pigment do not appear to constitute the majority of microorganisms in these cases. The relatively lower occurrence of these bacteria may help explain the relative stability and chronic nature of this condition.

Molecular methods such as PCR are more sensitive and specific than the conventional culture method, which is based on identification through the phenotypic characteristics of each microbial species (97). Molecular methods, however, are based on the detection of specific genomic sequences for each microbial species and can even discriminate clones within a single species (85). Although studies have determined that bacteria are the greatest etiological agent in pulp and periradicular disease, fungi have also been associated to root canal infection. Baumgartner et al. (8) used PCR to assess the content of infected root canals as well as cellulite aspirations and abscesses of endodontic origin for the presence of Candida albicans. The results indicate that PCR is an extremely sensitive molecular method and can be used to identify C. albicans directly in samples of endodontic infection.

PCR has been widely used to identify microbial species that are difficult or impossible to cultivate, as well as colonies within a species that exhibit a different phenotypic behavior and are therefore difficult to identify in culture procedures. PCR has a greater detection pattern than traditional microbiological identification methods and exhibits greater specificity under optimized conditions. Thus, the use of identification methods based on the knowledge of molecular biology has revolutionized medical microbiology and is broadening the horizons with regard to the actual profile of endodontic infection $(85,95)$.

\section{Oral Cancer}

One of the uses of PCR in dentistry is the detection of markers in the diagnosis and prognosis of some types of oral cancer $(45,52,81)$. For this purpose, PCR is a fast, easy method with a relatively low cost (45). Diagnoses, prognoses and treatment can be improved through the study and use of genetic markers identified by means of immunohistochemistry, PCR and other molecular biology procedures (67).

Squamous cell carcinoma of the oral cavity is generally accompanied by other types of aerodigestive tract carcinomas, such as oropharyngeal and esophageal carcinoma. Streptococcus anginosus is a bacterium that may be isolated in different parts of the body and has been isolated in squamous cell carcinoma of the head and neck. Through realtime PCR, S. anginosus can be detected with greater sensitivity and specific approximation in squamous cell carcinomas of the oral cavity (63).

Pre-malignant lesions of the head and neck have been studied extensively through genetic alterations. A genetic progression model has been established based on histological alterations that occur in the interior of the pre-malignant epithelium (15). HPV (Human Papillomavirus) has been employed in tumor progression in humans based on data from patients with cancer (29). Determining the moment of viral infections in these premalignant lesions could clarify the role of HPV in carcinogenesis and help guide future strategies for the prevention and early detection of squamous cell carcinoma of the head and neck. For such, a large number of studies have been conducted to detect the presence of HPV in head and neck epithelia through the use of a variety of laboratorial methods. Different techniques have been employed, including PCR, in situ hibridization, etc. Realtime PCR minimizes the risk of contamination, thereby becoming the ideal assay for HPV DNA detection (31).

The quantification of the number of genetic copies through real-time PCR using either DNA or RNA in studies on gene expression has been reported in the literature for human tumors, including breast cancer $(11,53,61)$, follicular lymphoma (30), stomach cancer (68), prostate cancer (34) and Ewing's sarcoma (78). In carcinoma of the head and neck, this new technology has been mainly applied for the detection of Epstein-Barr virus in nasopharynx cancer (55) and squamous cell carcinoma in lymph nodes (20). 


\section{CONCLUSIONS}

Based on the items research and described above, the following may be concluded:

- Methods associated to molecular biology have made excellent progress, with clear usefulness in diverse fields of medical science. The discovery of Polymerase Chain Reaction (PCR) introduced an technological advancement that is relevant for the detection of microorganisms, increasing the sensitivity, precision and accuracy of the diagnosis;

- In virology, the molecular detection and characterization of viral nucleic acids makes a complete viral characterization possible, thereby providing greater knowledge regarding the behavior of the virus and selected infectious processes. In the diagnosis of viruses, this enhances therapeutic treatment as well as clinical and epidemiological virus studies, thereby avoiding unnecessary treatments and reducing overall costs for patients;

- In mycology and parasitology, PCR technology favors the early identification of microorganisms, thereby enhancing epidemiological studies as well as the diagnosis of fungi and parasites, which is essential to the recognition of pathogens. Molecular tests assist in the decision-making process regarding fungal and parasitological diseases by assessing the effects of these microorganisms;

- In microbiology, PCR permits important, immediate observations for diagnostic tests in the detection of microorganisms. Genotyping allows the study of bacteria such as Mycobacterium tuberculosis. This is of tremendous worth for public health, favoring the early recognition and optimized treatment;

- In dentistry, molecular methods enhance knowledge regarding the diagnosis of infectious agents that lead to maxillofacial infections, thereby favoring the assessment of patients at risk for conditions such as caries, periodontal disease, endodontic infections and oral cancer. The publication of the PCR technique was a revolutionary watershed for medicine and science. It has become a standard diagnostic and research tool in dentistry, permitting the early diagnosis of the above-mentioned diseases.

\section{RESUMO}

\section{Princípios e aplicações da reação em cadeia de Polimerase em áreas médicas diagnósticas: uma revisão}

O advento dos métodos moleculares tem, nos últimos anos, revolucionado a detecção e caracterização dos microorganismos em diversas áreas médicas diagnósticas, tais como virologia, micologia, parasitologia, microbiologia e odontologia. Dentre as técnicas baseadas em biologia molecular, a PCR (Polymerase
Chain Reaction) trouxe enormes benefícios e desenvolvimentos científicos, se mostrando como um excelente caminho para a rápida detecção de patógenos, até mesmo aqueles de difícil cultivo. Derivada da PCR convencional, a PCR em Tempo Real se mostra como uma inovação tecnológica e vem conquistando espaço nos diagnósticos clínicos e nos laboratórios de pesquisa por apresentar a capacidade de gerar, além de resultados qualitativos, resultados quantitativos, se mostrando de forma mais rápida e precisa. Este trabalho de revisão tem por objetivo explorar a utilidade clínica da técnica de PCR convencional e em Tempo real nas diversas áreas médicas supracitadas, abrangendo seus principais usos e avanços, direcionando para o cotidiano profissional.

Palavras-chave: PCR convencional; PCR em Tempo Real; Biologia molecular; métodos de detecção molecular.

\section{REFERENCES}

1. Aliyu, S.H.; Marriot, R.K.; Curran, M.D.; Parmar, S.; Bentley, N.; Brown, N.M.; Brazier, J.S.; Ludlam, H. (2004). Real-time PCR investigation into the importance of Fusobacterium necrophorum as a cause of acute pharyngitis in general practice. J. Med. Microbiol. 53 (Pt 10): 1029-1035.

2. Andrews, J.M.; Brown, D.; Wise, R. (1996). A survey of antimicrobial susceptibility testing in the United Kingdom. J. Antimicrob. Chemother. 37 (1): 187-188.

3. Ashimoto, A.; Chen, C.; Bakker, I.; Slots, J. (1996). Polymerase chain reaction detection of 8 putative periodontal pathogens in subgingival plaque of gingivitis and advanced periodontitis lesions. Oral Microbiol. Immunol. 11 (4): 266-273.

4. Atkins, S.D.; Clark, I.M. (2004). Fungal molecular diagnostics: a mini review. J. Appl. Genet.45 (1): 3-15.

5. Bago, B.; Piche, Y.; Simon, L. (1998). Fluorescently-primed in situ PCR in arbuscular mycorrhizas. Mycol. Res. 102 (12): 1540-1544.

6. Bartosch, S.; Fite, A.; Macfarlane, G.T.; Mcmurdo, M.E. (2004) Characterization of bacterial communities in feces from healthy elderly volunteers and hospitalized elderly patients by using realtime PCR and effects of antibiotic treatment on the fecal microbiota. Appl. Environ. Microbiol. 70 (6): 3575-3581.

7. Bates, J.A.; Taylor, E.J.A.; Kenyon, D.M.; Thomas, J.E. (2001). The application of real-time PCR to the identification, detection and quantification of Pyrenophora species in barley seed. Mol. Plant. Pathol. 2 (1): 49-57.

8. Baumgartner, J.C.; Watts, C.M.; Xia, T. (2000). Occurrence of Candida albicans in infections of endodontic origin. J. Endod. 26 (12), 695-8.

9. Bell, C.A.; Uhl, J.R.; Hadfield, T.L. et al. (2002). Detection of Bacillus anthracis DNA by LightCycler PCR. J. Clin. Microbiol. 40 (8 ): 2897- 2902.

10. Bernard, P.S.; Wittwer, C.T. (2000). Homogenous amplification and variant detection by fluorescent hybridization probes. Clin. Chem. 46 (2): 147-8.

11. Bièche, I.; Olivi, M.; Champème, M.H.; Vidaud, D.; Lidereau, R.; Vidaud, M. (1998). Novel approach to quantitative polymerase chain reaction using real-time detection: application to the detection of gene amplification in breast cancer. Int. J. Cancer, 78 (5): 661666.

12. Bogen, G.; Slots, J. (1999); Black-pigmented anaerobic rods in closed periapical lesions. Int. Endod. J. 32 (3): 204-210. 
13. Bohm, J.; Hahn, A.; Schubert, R.; Bahnweg, G.; Adler, N.; Nechwatal, J.; Oehlann, R.; Osswald, W. (1999). Real-time quantitative PCR: DNA determination in isolated spores of the mycorrhizal fungus Glomus mosseae and monitoring of Phytophora infestans and Phytophora citricola in their respective host plants. J. Phytopathol. 147 (7-8): 409-416.

14. Bruce, A.; Bray, D.; Johnson, A.; Lewis, J.; Rass, M.; Roberts, K.; Walter, P. (1999). Fundamentos da biologia celular: uma introdução à biologia molecular da célula. Porto Alegre: Artes Médicas Sul.

15. Califano, J.; Van Der Riet, P.; Westra, W.; Nawroz, H.; Clayman, G.; Piantadose, S.; Corio, R.; Lee, D.; Greenberg, B.; Koch, W.; Sidransky, D. (1996). Genetic progression model for head and neck cancer: implications for field cancerization. Cancer Res. 56 (11): 24882492.

16. Cardullo, R.A.; Agrawal, S.; Flores, C.; Zamecnik, P.C.; Wolf, D.E. (1988). Detection of nucleic acid hybridization by nonradiative fluorescence resonance energy transfer. Proc. Natl. Acad. Sci. USA. 85 (23): 8790- 8794.

17. Chen, C.; Slots, J. (1999). Microbiological tests for Actinobacillus actinomycetemcomitans and Porphyromonas gingivalis. Periodontol. 2000. 20: 53-64.

18. Cockerill, F.R. (2003). Application of rapid-cycle Real-Time polymerase chain reaction for diagnostic testing in the clinical microbiology laboratory. Arch. Pathol. Lab. Med. 127 (9): 11121120 .

19. Cortelli, S.C.; Jorge, A.O.C.; Querido, S.M.R.; Cortelli, J.R. (2003). PCR e cultura na detecção subgengival de Actinobacillus actinomycetemcomitans: estudo comparativo. Cien. Odontol. Bras. 6 (2): 58-64.

20. Cortesina, G.; Martone, T.; Galeazzi, E.; Olivero, M.; De Stefani, A.; Bussi, M.; Valente, G.; Comoglio, P.M.; Di Renzo, M.F. (2000). Staging of head and neck squamous cell carcinoma using the MET oncogene product as marker of tumor cells in lymph node metastases. Int. J. Cancer. 89 (3): 286-292.

21. Cullen, D.W.; Lees, A.K.; Toth, I.K.; Duncan, J.M. (2001). Conventional PCR and real-time PCR detection of Helminthosporium solani in soil and potato tubers. Eur. J. Plant. Pathol. 107: 387-398.

22. Dahllof, I. (2002). Molecular community analysis of microbial diversity. Curr. Opin. Biotechnol. 13 (3): 213-217.

23. Damen, M.; Cuypers, H.T.; Zaaijer, H.L.; Reesink, H.W.; Schaasberg, W.P.; Gerlich, W.H.; Niesters, H.G.; Lelie, P.N. (1996). International collaborative study on the second EUROHEP HCV-RNA reference panel. J. Virol. Methods. 58 (1-2): 175-185.

24. Doungudomdacha, S.; Rawlison, A.; Douglas, W.I. (2000). Enumeration of Porphyromonas gingivalis, Prevotella intermedia and Actinobacillus actinomycetemcomitans in subgingival plaque samples by a quantitative-competitive PCR method. J. Med. Microbiol. 49 (10): 861-874.

25. Espy, M.J.; Uhl, J.R.; Mitchell, P.S.; Thorvlson, J.N.; Svien, K.A.; Wold, A.D.; Smith, T.F. (2000). Diagnosis of herpes simplex virus infections in the clinical laboratory by LightCycler PCR. J. Microbiol. 38 (2): 795-799.

26. Espy, M.J.; Cockerill, F.R.; Meyer, R.F.; Bowen, M.D.; Poland, G.A.; Hadfield, T.L.; Smith, T.F. (2002). Detection of smallpox virus DNA by LigthtCycler PCR. J. Clin. Microbiol. 40 (6): 1985-1988.

27. Furuta, Y.; Ohtani, F.; Sawa, H.; Fukuda, S.; Inuyama, Y. (2001). Quantitation of varicella-zoster virus DNA in patients with ramsay hunt syndrome and zoster sine herpete. J. Clin. Microbiol. 39 (8): 2856-2859.

28. Gibson, U.E.; Heid, C.A.; Williams, P.M. (1996). A novel method for real time quantitative RT-PCR. Genome Res. 6 (10): 995-1001.

29. Gillison, M.L.; Koch, W.M.; Capone, R.B.; Spafford, M.; Westra, W.H.; Wu, L.; Zahurak, M.L.; Daniel, R.W.; Viglione, M.; Symer, D.E.; Shah, K.V.; Sidransky, D. (2000). Evidence for a causal association between human papillomavirus and a subset of head and neck cancers. J. Natl. Cancer Inst. 92 (9): 709-720.

30. Goff, L.K.; Neat, M.J.; Crawley, C.R.; Jones, L.; Jones, E.; Lister, T.A.; Gupta, R.K. (2000). The use of real-time quantitative polymerase chain reaction and comparative genomic hybridization to identify amplification of the REL gene in follicular lymphoma. Br. J. Haematol. 111 (2): 618-625.

31. Ha, P.K.; Pai, S.I.; Westra, W.H.; Gillison, M.L.; Tong, B.C.; Sidransky, D.; Califano, J.A. (2002). Real-Time quantitative PCR demonstrates low prevalence of human papillomavirus type 16 in premalignant and malignant lesions of the oral cavity. Clin. Cancer Res. 8 (5): 1203-1209.

32. Hayashi, F.; Okada, M.; Zhong, X.; Miura, K. (2001). PCR deteccion of Capnocytophaga species in dental plaque samples from children aged 2 to 12 years. Microbiol. Immunol. 45 (1): 17-22.

33. Heid, C.A.; Stevens, J.; Livak, K.J.; Williams, P.M. (1996). Genome Res. 6 (10): 986-994.

34. Helenius, M.A.; Saramaki, O.R.; Linja, M.J.; Tammela, T.L.; Visakorp, T. (2001). Amplification of urokinase gene in prostate cancer. Cancer Res. 61 (14): 5340-5344.

35. Heuer, H.; Krsek, M.; Baker, P. Smalla, K.; Wellington, E.M.H. (1997). Analysis of actinomycete communities by specific amplification of genes encoding 16S rRNA and gel-electrophoretic separation in denaturing gradients. Appl. Environ. Microbiol. 63 (8): 3233-3241.

36. Helweg-Larsen, J.; Jensen, J.S.; Benfield, T.; Svendesen, U.G.; Lundgren, J.D.; Lundgren, B. (1998). Diagnostic use of PCR for detection of Pneumocystis carinii in oral wash samples. J. Clin. Microbiol. v. 36 (7): 2068-2062.

37. Helweg-Larsen, J.; Jensen, J.S.; Dohn, B.; Benfield, T.; Svendesen, U.G.; Lundgren, B. (2002). Detection of Pneumocystis DNA in samples from patients suspected of bacterial pneumonia- a case control study. BMC Infect. Dis. 25, 2:28. Epub.

38. Hirasawa, M.; Takada, K. (2003). A new selective medium for Streptococcus mutans and the distribution of $S$. mutans and S. sobrinus and their serotypes in dental plaque. Caries Res. 37 (2): 212-217.

39. Hodinka, R.L. (1998). The clinical utility of viral quantitation using molecular methods. Clin. Diagn. Virol. 10 (1): 25-47.

40. Huijsdens, X.W.; Linskens, R.K.; Mak, M.; Meuwissen, S.G.; Vandenbroucke-Grauls, C.M.; Savelkoul, P.H. (2002). Quantification of bacteria adherent to gastrointestinal mucosa by real-time PCR. $J$. Clin. Microbiol. 40 (12): 4423-4427.

41. Igarashi, T.; Ichikawa, K.; Yamamoto, A.; Goto, N. (2001). Identification of mutans streptococcal species by the PCR products of the dex genes. J. Microbiol. Methods. 46 (2): 99-105.

42. Igarashi, T.; Yano, Y.; Yamamoto, A.; Sasa, R.; Goto, N. (2001). Identification of Streptococcus salivarius by PCR and DNA probe. Lett Appl. Microbiol. 32 (6): 394-397.

43. Igarashi, T.; Yamamoto, A.; Goto, N. (1996). Rapid identification of mutans streptococcal species. Microbiol. Immunol. 40 (11): 867871 .

44. Jordens, J.Z.; Lanham, S.; Pickett, M.A.; Amarasekara, S.; Aberywickrema, I.; Watt, P.J. (2000). Amplification with molecular beacon primers and reverse line blotting for the detection and typing of human papillomaviruses. J. Virol. Methods, 89 (1-2 ): 29-37.

45. Kariyazono, H.; Ohno, T.; Ihara, K.; Igareshi, H.; Joh-O, K.; Ishikawa S. et al. (2001). Rapid detection of the 22q 11.2 deletion with quantitative real-time PCR. Mol. Cell. Probes, 15 (2): 71-73.

46. Kearns, A.M.; Turner, A.J.L.; Taylor, C.E.; George, P.W.; Freeman, R.; Gennery, A.R. (2001). LightCycler-based quantitative PCR for rapid detection of human herpes virus 6 DNA in clinical material. $J$. Clin. Microbiol. v. 39 (8): 3020-3021.

47. Kim, Y.; Flynn, T.R.; Donoff, R.B.; Wong, D.T.W.; Tood, R. (2002). The gene: the polymerase chain reaction and its clinical application. J. Oral Maxillofac. Surg. 60 (7): 808-815. 
Valones, M.A.A. et al.

48. Kimura, S.; Ooshima, T.; Takiguchi, M.; Sasaki, Y.; Amano, A.; Morisaki, I.; et al. (2002). Periodontopathic bacterial infection in childhood. J. Periodontol. 73 (1): 20-26.

49. Kostrikis, L.G.; Tyagi, S.M.; Mhlanga, M.; Ho, D.D.; Kramer, F.R. (1998). Molecular Beacons: Spectral Genotyping of Human Alleles. Science. 279 (5354): 1228-1229.

50. Kubista, M.; Andrade, J.M.; Bengtsson, M.; Forootan, A.; Jonák, J.; Lind, K.; Sindelka, R.; Sjoback, R.; Sjogreen, B.; Strombom, L.; Stahlberg, A.; Zoric, N. (2006). The real-time polymerase chain reaction. Mol. Aspects Med. 27 (2-3): 95-115.

51. Kutyavin, I.V.; Afonina, I.A.; Mills, A.; Gorn, V.V.; Luckhtanov, A.; Belousov, E.S.; Singer, M.J.; Walburger, D.K.; Lokhov, S.G.; Gall, A.A.; Dempcy, R.; Reed, M.W.; Meyer, R.B.; Hedgpeth J. (2000). 3'- minor groove binder - DNA probes increase sequence specificity at PCR extension temperatures. Nucleic Acids Res. 28 (2): 655-61.

52. lee, b.k.; diebel, e. neukam, f.w.; wiltfang, j.; ries, j. (2001). Diagnostic and prognostic relevance of expression of human telomerase subunits in oral cancer. Int. J. Oncol. 19 (5): 1063-1068.

53. Lehmann, U.; Glockner, S.; Kleeberger, W.; Feist, H.; Von Wasielewski, R.; Kreipe, H. (2000). Detection of gene amplification in archival breast cancer specimens by laser-assisted microdissection and quantitative real-time polymerase chain reaction. Am. J. Pathol. 156 (6): 1855-1864.

54. Lyons, S.R.; Griffen, A.L.; Leys, E.J. (2000). Quantitative real-time PCR for Porphyromonas gingivalis and total bacteria. J. Clin. Microbiol. 38 (6): 2362-2365.

55. Lo, Y.M.; Chan, A.T.; Chan, L.Y.; Leung, S.F.; Lam, C.W.; Huang, D.P.; Johnson, P.J. (2000). Molecular prognostication of nasopharyngeal carcinoma by quantitative analysis of circulating Epstein-Barr virus DNA. Cancer Res. 60 (24): 6878-6881.

56. Mackay, I.M.; Arden, K.E.; Nitsche, A. (2002). Real-time PCR in virology. Nucl. Ac. Res. 30 (6): 1292-1305.

57. Mauchline, T.H.; Kerry, B.R.; Hirsch, P.R. (2002).Quantification in soil and the rhizosphere of the nematophagous fungus Verticillium chamydosporium by competitive PCR and comparison with selective plating. Appl. Environ. Microbiol. 68 (4): 1846-1853.

58. Matsuki, T.; Watanabe, K.; Fujimoto, J.; Kado, Y.; Takada, T.; Matsumoto, K.; Tanaka, R. (2004). Quantitative PCR with 16S rRNAgene-targeted species-specific primers for analysis of human intestinal bifidobacteria. Appl. Environ. Microbiol. 70 (1): 167-173.

59. Matto, J.; Saarela, M.; Alauusua, S.; Oja, V.; Jousimies-Somer, H.; Asikainen, S. (1998). Detection of Porphyromonas gingivalis from saliva by PCR by using a simple sample-processing method. J. Clin. Microbiol. 36 (1): 157-160.

60. Maccartney, H.A.; Foster, S.J.; Fraaue, B.A.; Ward, E. (2003). Molecular diagnostics for fungal plant pathogens. Pest. Manag. Sci. 59 (2): 129-142.

61. Mitas, M.; Mikhitarian, K.; Walters, C.; Baron, P.L.; Elliot, B.M.; Brothers, T.E.; Robinson, J.G.; Metcalf, J.S.; Palesch, Y.Y.; Zhang, Z.; Gillanders, W.E.; Cole, D.J. (2001). Quantitative real-time RTPCR detection of breast cancer micrometastasis using a multigene marker panel. Int. J. Cancer. 93 (2): 162-171.

62. Morillo, J.M.; Lau, L.; Sanz, M.; Herrera, D.; Silva, A. (2003). Quantitative real time PCR based on single copy gene sequence for detection of Actinobacillus actinomycetemcomitans and Porphyromonas gingivalis. J. Periodont. Res. 38 (5): 518-524.

63. Morita, E.; Narikiyo, M.; Yano, A.; Nishimura, E.; Igaki, H.; Sasaki, H.; Terada, M.; Hanada, N.; Kawabe, R. (2003). Different frequencies of Streptococcus anginosus infection in oral cancer and esophageal cancer. Cancer Sci. 94 (6): 492-496.

64. Morrison, T.B.; Weis, J.J.; Wittwer, C.T. (1998). Quantification of low-copy transcripts by continuous SYBR Green I monitoring during amplification. BioTechniques. 24 (6): 954-958,960,962.

65. Mullally, B.H.; Dace, B.; Shelburne, C.E.; Wolff, L.F.; Coulter, W.A. (2000). Prevalence of periodontal pathogens in localized and generalized forms of early-onset periodontitis. J. Periodont. Res. 35 (4): 232-241.

66. Mullis, K.B. (1990). Target amplification for DNA analysis by the polymerase chain reaction. Ann. Biol. Clin. 48 (8): 579-582.

67. Murdoch-Kinch, C.A. (1999).Oral medicine: advances in diagnostic procedures. J. Calif. Dent. Assoc. 27 (10): 773-784.

68. Nakanishi, H.; Kodera, Y.; Yamamura, Y.; Ito, S.; Kato, T.; Ezaki, T.; Tatematsu, M. (2000). Rapid quantitative detection of carcinoembryonic antigen-expressing free tumor cells in the peritoneal cavity of gastric-cancer patients with real-time RT-PCR on the lightcycler Int. J. Cancer. 89 (5): 411-417.

69. Nakano, K.; Nomura, R.; Nakagawa, I.; Hamada, S.; Ooshima, T. (2004). Demonstration of Streptococcus mutans with a cell wall polysaccharide specific to a new serotype $\mathrm{K}$, in the human oral cavity. J. Clin. Microbiol. 42 (1): 198-202.

70. Nazarenko, I.A.; Bhatnagar, S.K.; Hohman, R.J. (1997). A closed tube format for amplification and detection of DNA based on energy transfer. Nucleic Acids Res. 25 (12): 2516 -2521.

71. Niesters, H.G.M. (2001). Quantitation of viral load using real- time amplification techniques. Methods. 25 (4): 419-429.

72. Niesters, H.G.M. (2004). Molecular and diagnostic clinical virology in real time. Clin. Microbiol. Infect. 10 (1): 5-11.

73. Novais, C.M.; Pires-Alves, M.; Silva, F.F. (2004). PCR em tempo real. Rev. Biotecnol. Cienc. Des. ed. 33.

74. Nygren, J.; Svanvik, N.; Kubista, M. (1998). The interaction between the fluorescent dye thiazole orange and DNA. Biopolymers. 46 (1): 39-51.

75. Okada, M.; Hayashi, F.; Nagasaka, N. (2000). Detection of Actinobacillus actinomicetemcomitans and Porphyromonas gingivalis in dental plaque samples from children 2 to 12 years of age. J. Clin. Periodontol. 27 (10): 763-768.

76. Okada, M.; Soda, Y.; Hayashi, F.; Doi, T.; Suzuki, J.; Miura, K.; et al. (2002). PCR detection of Streptococcus mutans and S. sobrinus in dental plaque samples from Japanese pré-school children. J. Med. Microbiol. 51 (5): 443-447.

77. Parra, B.; Slots, J. (1996). Detection of human viruses in periodontal pockets using polymerase chain reaction. Oral Microbiol. Immunol. 11 (5): 289-293.

78. Peter, M.; Gilbert, E.; Delattre, O. (2001). A multiplex real-time pcr assay for the detection of gene fusions observed in solid tumors. Lab. Invest. 81 (6): 905-912.

79. Quint, W.G.V.; Heijtink, R.A.; Schirm, J.; Gerlich, W.H.; Niesters, H.G.M. (1995). Reliability of methods for hepatitis B virus DNA detection. J. Clin. Microbiol. 33 (1): 225-228.

80. Ranjard, L.; Poly, F.; Lata, J.C.; Mougel, C.; Thioulouse, J.; Nazaret, S. (2001). Characterization of bacterial and fungal soil communities by automated ribosomal intergenic spacer analysis fingerprints: Biological e Methodological variability. Appl. Environ. Microbiol. 67 (10): 4479-4487.

81. Reis, P.P.; Rogatto, S.R.; Kowalski, L.P.; Nishimoto, I.N.; Montovani, S.C.; Corpus, G. et al. (2002). Quantitative real-time PCR identifies a critical region of deletion on $22 \mathrm{q} 13$ related to prognosis in oral cancer. Oncogene.21 (42): 6480-6487.

82. Richard, B.; Groisillier, A.; Badet, C.; Dorignac, G.; Lonvaud-Funel, A. (2001). Identification of salivary Lactobacillus rhamnosus species by DNA profiling and a specific probe. Res. Microbiol. 152 (2): 157-165.

83. Riggio, M.P.; Lennon, A. (1997). Rapid identification of Actinobacillus actinomycetemcomitans, Haemophilus aphrophilus, and Haemophilus paraphrophilus by restriction enzyme analysis of PCR-amplified 16S rRNA genes. J. Clin. Microbiol. 35 (6): 1630-1632.

84. Ririe, K.M.; Rasmussen, R.P.; Wittwer, C.T. (1997). Product differentiation by analysis of DNA melting curves during the polymerase chain reaction. Anal. Biochem. 245 (2): 154-160.

85. Rôças, I.N. (2004). Polymerase Chain Reaction-PCR. In: LOPES, H.P.; SIQUEIRA Jr. Endodontia:Biologia e Técnica, Box 10-1, 2 ed. Rio de Janeiro: Guanabara Koogan. 
86. Rupf, S.; Kneist, S.; Merte, K.; Eschrich, K. (1999). Quantitative determination of Streptococcus mutans by using competitive polymerase chain reaction. Eur. J. Oral Sci. 107 (2): 75-81.

87. Saarela, M.; Hannula, J.; Matto, J.; Asikainen, S.; Alaluusua, S. (1996). Typing of mutans streptococci by arbitrarily primed polymerase chain reaction. Arch. Oral Biol. 41 (8-9): 821-826.

88. Sakamoto, M.; Takeuchi, Y.; Umeda, M.; Ishikawa, I.; Benno, Y. (2001). Rapid deteccion and quantification of live periodontopathic bacteria by real time PCR. Microbiol. Immunol. 45 (1): 39-44.

89. Sakamoto, M.; Takeuchi, Y.; Umeda, M.; Ishikawa, I.; Benno, Y.; Nakase, T. (1999). Detection of Treponema socranskii associated with human periodontitis by PCR. Microbiol. Immunol. 43 (5): 485-490.

90. Santos, C.F.; Sakai, V.T.; Machado, M.A.A.M.; Schippers, D.N.; Greene, A.S. (2004). Reverse transcription and polymerase chain reaction: principles and applications in dentistry. J. Appl. Oral Sci. 12 (1): 1-11.

91. Saygun, I.; Sahin, S.; Ozdemir, A.; Kurtis, B.; Yapar, M.; Kubar, A. et al. (2002). Detection of human viruses in patients with chronic periodontitis and the relationship between viruses and clinical parameters. J. Periodontol. 73 (12): 1437-1443.

92. Schuurman, R.; Descamps, D.; Weverling, G.J.; Kaye, S.; Tijnagel, J.; Williams, I.; Van Leeuwen, R.; Tedder, R.; Boucher, C.A.; BrunVezinet, F.; Loveday, C. (1996). Multicenter comparison of three commercial methods for quantification of human immunodeficiency virus type 1 RNA in plasma. J. Clin. Microbiol. 34 (12): 3016-3022.

93. Shelburne, C.E.; Gleason, R.M.; Germaine, G.R.; Wolff, L.F.; Mullally, B.H.; Coulter, W.A. et al. (2002). Quantitative reverse transcription polymerase chain reaction analysis of Porphyromonas gingivalis gene expression in vivo. J. Microbiol. Meth. 49 (2): 147-156.

94. Silva, L.A.F.; Passos, N.S. (2002). DNA Forense. Coleta de amostras biológicas em locais de crimes para estudo de DNA. Maceió: UFAL.

95. Siqueira Jr., J.F.; Rôças, I.N. (2003). A 16 rDNA-based nested PCR protocol to detect Campylobacte gracilis in oral infections. Pesqui. Odontol. Bras. 17 (2): 142-146.

96. Siqueira Jr., J.F.; Rôças, I.N. (2003). PCR methodology as a valuable tool for identification of endodontic pathogens. J. Dent. 31 (5): 333-339.

97. Slots, J. (1986). Rapid identification of important periodontal microorganisms by cultivation. Oral Microbiol. Immunol. 1 (1): 48-57.

98. Song, Y. (2005). PCR-based diagnostics for anaerobic infections. Anaerobe. 11 (1-2): 79-91.

99. Speers, D.J.; Ryan, S.; Harnett, G.; Chidlow, G. (2003). Diagnosis of malaria aided by polymerase chain reaction in two cases with lowlevel parasitaemia. Inter. Med. J. 33 (12): 613-615.

100. Speers, D.J. (2006). Clinical applications of molecular biology for infectious diseases. Clin. Biochem. Rev. v. 27 (1): 39-50.

101. Spolidorio, D.M.P.; Spolidorio, L.C. (2005). Técnicas básicas de biologia molecular. In: ESTRELA, C. Metodologia cientificaCiência-Ensino-Pesquisa. São Paulo: Artes Médicas.

102. Sterflinger, K.; Krumbien, W.E.; Schwiertz, A. (1998). A protocol for PCR in situ hybridization of hypomycetes. Int. Microbiol. 1 (3): 213-220.

103. Takeuchi, Y.; Makoto, U.; Sakamoto, M.; Benno, Y.; Huang, Y.; Ishikawa, I. (2001). Treponema socranskii, Treponema denticola, and Porphyromonas gingivalis are associated with severity of periodontal tissue destruction. J. Periodontol. 72 (10): 1354-1363.

104. Tran, S.D.; Rudney, J.D. (1999). Improved multiplex PCR using conserved and species-specific 16S rRNA gene primer for simultaneous detection. J. Clin. Microbiol. 37 (11): 3504-3508.

105. Truong, T.L.; Menard, C.; Mouton, C.; Trahan, L. (2000). Identification of mutans and other oral Streptococci by random amplified polymorphic DNA analysis. J. Med. Microbiol. 49 (1): $63-71$.

106. Tyagi, S.; Kramer, F.R. (1996). Molecular beacons: probes that fluoresce upon hybridization. Nat. Biotechnol. 14 (3): 303-308.

107. Tyagi, S.; Bratu, D.P.; Kramer, F.R. (1998). Multicolor molecular beacons for allele discrimination. Nat. Biotechnol. 16 (1): 49-53.

108. Whiley, R.A.; Beighton, D. (1998). Current classification of the oral streptococci. Oral Microbiol. Immunol. 13 (4): 195-216.

109. Whitcombe, D.; Brownie, J.; Gillard, H.L.; Mckechnie, D.; Theaker, J.; Newton, C.R.; Little, S. (1998). A homogeneous fluorescence assay for PCR amplicons: its application to real-time, single-tube genotyping. Clin. Chem. 44 (5): 918-923.

110. Whitcombe, D.; Theaker, J.; Guy, S.P.; Brown, T.; Little, S. (1999). Detection of PCR products using self probing amplicons and fluorescence. Nat. Biotechnol. 17 (8): 804-807.

111. Williamson, E.M.C.; Leeming, J.P.; Palmer, H.M.; Steward, C.G.; Warnock, D.; Marks, D.I.; Millar, M.R. (2000). Diagnosis of invasive aspergillosis in bone marrow transplant recipients by polymerase chain reaction. Br. J. Haematol. 108 (1): 132-139.

112. Winton, L.M.; Stone, J.K.; Watrud, L.S.; Hansen, E.M. (2002) Simultaneous one-tube quantification of host and pathogen DNA with real-time polymerase chain reaction. Phytopathology. 92: 102-116.

113. Wittwer, C.T.; Herrmann, M.G.; Moss, A.A.; Rasmussen, R.P. (1997). BioTechniques. 22 (1): 130-131, 134-138.

114. Wolk, D.; Mitchell, P.S.; Patel, R. (2001). Principles of molecular microbiology testing methods. In: COCKERILL, F. ed. Infectious Diseases Clinics of North America. Philadelphia: WB Saunders.

115. Wu, P.; Brand, L. (1994). Resonance energy transfer: methods and applications Anal.Biochem. 218 (1): 1-13.

116. Yang, S.; Rothman, R.E. (2004). PCR-based diagnostics for infectious diseases: uses, limitations, and future applications in acute-care settings. Lancet Infect. Dis. 4 (6): 337-348.

117. Yoo, S.Y.; Kim, P.S.; Hwang, H.K.; Lim, S.H.; Kim, K.W.; Choe, S.J.; Min, B.M.; Kook, J.K. (2005). Identification of non-mutans Streptococci organisms in dental plaques recovering on mitissalivarius bacitracin agar medium. J. Microbiol. 43 (2): 204-208.

118. YOSHIDA, A.; SUZUKI, N.; NAKANO, Y.; KAWADA, M.; OHO, T.; KOGA, T. (2003). Development of a 5' nuclease-based real-time PCR assay for quantitative detection of cariogenic dental pathogens Streptococcus mutans and Streptococcus sobrinus. J. Clin. Microbiol. 41 (9): 4438-4441.

119.Zariffard, M.R.; Saifuddin, M.; Sha, B.E.; Spear, G.T. (2002). Detection of bacterial vaginosis-related organisms by real-time PCR for Lactobacilli, Gardnerella vaginalis and Mycoplasma hominis. FEMS Immunol. Med. Microbiol. 34 (4): 277-281.

120.Zerr, D.M.; Huang, M.L.; Corey, L.; Erickson, M.; Parker, H.L.; Frenkel, L.M. (2000). Sensitive method for detection of human herpesvirus 6 and 7 in saliva collected in field studies. J. Clin. Microbiol. 38 (5): 1981-1983. 